\title{
NRTSC
}

NUOLEAR REACTOR TECHNOLOGY

AND SCIENTIFIC COMPUTATIONS

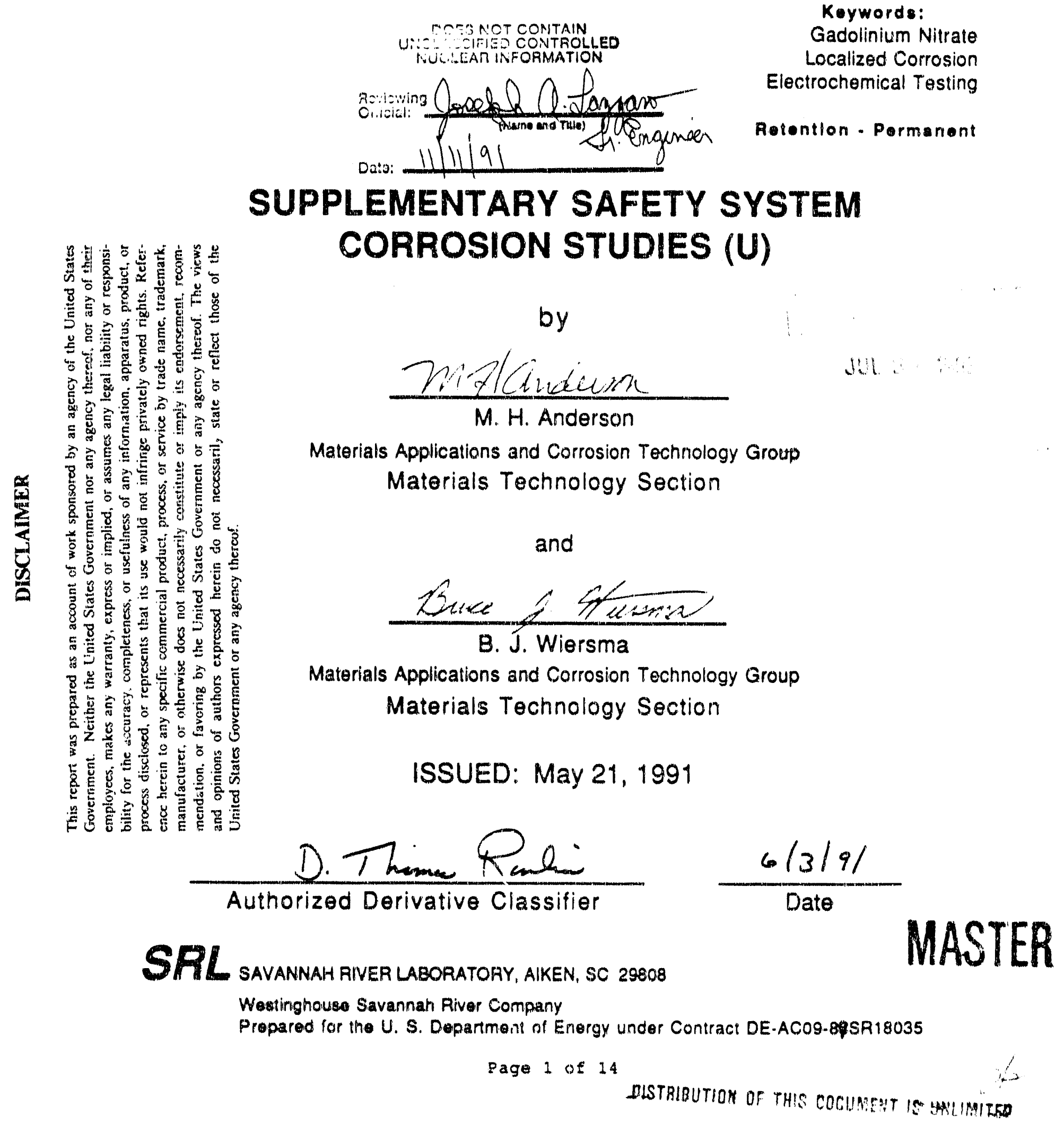


DOCUMENT: WSRC-TR-91-389

SAL-MTS.913001

DATE:

May 21, 1991

IITLE:

\section{SUPPLEMENTARY SAFETY SYSTEM CORROSION STUDIES (U)}

\section{APPROVALS}

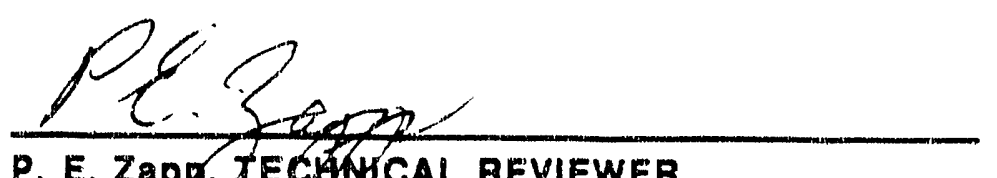

DATE: $6-3-91$ MATERIALS TECHNOLOGY

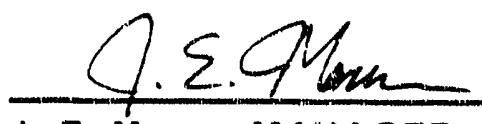

J. E. Marra, MANAGER MATERIALS TECHNOLOGY
DATE: $3-\operatorname{sun}-91$
T. Copelass.

T. L. Capoletti, MANAGER MATERIALS TECHNOLOGY
DATE:

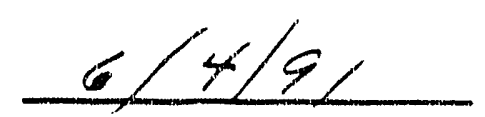




\section{DISCLAIMER}

This report was prepared as an account of work sponsored by an agency of the United States Government. Neither the United States Government nor any agency thereof, nor any of their employees, makes any warranty, express or implied, or assumes any legal liability or responsibility for the accuracy, completeness, or usefulness of any information, apparatus, product, or process disclosed, or represents that its use would not infringe privately owned rights. Reference herein to any specific commercial product, process, or service by trade name, trademark, manufacturer, ol otherwise does not necessarily constitute or imply its endorsement, recommendation, or favoring by the United States Government or any agency thereof. The views and opinions of authors expressed herein do not necessarily state or reflect those of the United States Government or any agency' thereof.

This report has been reproduced directly from the best available copy.

Available to DOE and DOE contractors from the Office of Scientific and Technical Information, P.O. Box 62, Oak Ridge, TN 37831; prices available from (615) 576-8401, FTS 626-8401.

Availatle to the public from the National Techncial Information Service, U.S. Department of Commerce, 5285 Port Royal Rd., Springfield, VA 22161. 


\section{INTRODUCTION AND SUMMARY}

This rnemorandum presents experimental data from electrochemical and immersion tests to support the continued use of two sections of nonconforming steel in the Supplementary Safety System (SSS). The Reactor Corrosion Mitigation Committee (RCMC) met on May 16, 1991 to evaluate materials that had been installed in the SSS. The materials lacked complete Corrosion Evaluation (CE) and/or Certified Mill Test Reports (CMTR) ${ }^{1}$ and had been installed during recent modifications (Project S-4332). Items that lacked proper documentation included AISI Type 304 stainless steel (304) instrument tubing (0.375" OD) associated with the pressure transmitters and a two-foot section of 304 pipe located on the far side of the system downstream of the pneumatic valves. The RCMC emphasized the need for experimental data to support the general belief that these components could remain in the system until the next scheduled long shut-down.

Cyclic potentiodynamic polarization scans were performed on sensitized and solution-annealed 304 samples in as-mixed and acidified $\mathrm{Gd}\left(\mathrm{NO}_{3}\right)_{3}$, or "ink". solutions at room ternperature to determine the susceptibility of 304 to localized corrosion in this environment ${ }^{2}$. No localized attack was observed on the solution annealed or sensitized 304 in the $\mathrm{Gd}\left(\mathrm{NO}_{3}\right)_{3}$ solution. These tests revealed no significant differences in the behavior of the sensitized and solution-annealed 304 in gadolinium nitrate solution. Therefore, localized corrosion of the nonconforming components is not anticipated, and the performance of the nonconforming components should not differ from that of corrosion evaluated and certified materials. Previous studies have shown that AISI Type 304L stainless steel (304L) did not pit during a three-month exposure in gadolinium nitrate solutions of $\mathrm{pH} 2$ or 5 . These solutions also contained Rhodarnine B, a chloride containing dye which increased the pitting potential and the aggressiveness of the test solution. ${ }^{3}$ These combined results support the continued use of the nonconforming steels until replacement can be made at the next scheduled long shut-down.

\section{EXPERIMENTAL PROCEDURE}

Cyclic polarization scans werc conducted according to ASTM standard G61-86. A P'rinceton Applied Research (PAR) Model 273A Potentiostat/Galvanostat was utilized to control the electrical potential during the test. PAR 342 corrosion measurement software was used 10 record the current response. The scan rate selectled for these experiments was $0.166 \mathrm{mV} / \mathrm{s}$. The test solution was deaerated with niliogen during the test. The potential was measured with respect to a saturated calomel electrode (SCE). The potential of this electrode was checked against an unused SCE prior to each test. At the completion of each test, the specimen was examined under a light microscope at a magnification of $70 \mathrm{X}$ to see if pitting had occurred. 
A gadolinium nitrate solution was prepared in the is-mixed and acidified conditions. The concentration of gadolinium in each sulution was $0.22 \mathrm{~g} / \mathrm{ml}$. The $\mathrm{pH}$ of the as-mixed solution was 3.39. For the acidified solution, nitric acid was added to reduce the $\mathrm{pH}$ to 2.07 . The solution was deaerated with a nitrogen gas purge, and remained at a temperature of $23^{\circ} \mathrm{C}$ for the duration of each test.

304 stainless steel was tested in the solution annealed and furnace sensitized conditions. The carbon content of the 304 was certified by the manufacturer to be $0.06 \%$ (Attachment 1). In order to simulate the sensitized condition two specimens were held in a furnace at $650{ }^{\circ} \mathrm{C}$, one for 6 hours and another for 24 hours. The degree to which the specimens had been sensitized was evaluated qualitatively with the oxalic acid etch test and then quantitatively with electrochemical potentiokinetic reactivation (EPR). The oxalic acid etch test consists of applying a current density of $1 \mathrm{~A} / \mathrm{cm}^{2}$ to the specimen for 90 seconds in a 10\% oxalic acid solution and then observing the microstructure on a metallograph at a magnification of 250X. For EPR, the specimen is passivated in a $0.5 \mathrm{M} \mathrm{H}_{2} \mathrm{SO}_{4}+0.01 \mathrm{M} \mathrm{KSCN}$ solution and then the potential is scanned in the cathodic direction lowards the open circuit potential. 4 As the potential is scanned, the current, which is an indicator of the localized dissolution occurring at the grain boundaries, is measured. At the completion of the scan, the total electrical charge density passed during the scan is calculated to determine the degree of sensitization. EPR values greater than 2 $\mathrm{C} / \mathrm{cm}^{2}$ indicate that the material is susceptible to intergranular stress corrosion cracking (IGSCC). ${ }^{5}$

\section{RESULTS AND DISCUSSION}

\section{Microstructure Evaluation}

Welding of austenitic stainless steels results in a sensitized microstructure in a narrow band adjacent to the weld. Sensitization occurs at the grain boundaries where chromium carbides have precipitated thereby leaving a chromium depleted region. Due to the depletion of the chromiurn the region is susceptible to intergranular attack.

The oxalic acid etch test provides a qualitative estimate of the degree of sensitization. During the test the carbides are preferentially elched indicating the presence of chromium depleted regions. There are three structures which may result:

1. Step Steps at grain boundaries; non-sensitized

2. Dual Grains partially encircled by carbides; sensitized

3. Ditch Grains completely encircled by carbides; heavily sensitized 
Figure 1 shows the solution annealed specimen after the oxalic acid test. A step microstructure is evident indicating that the material is not sensitized. Figures 2 and 3 show the specimens which had been heat treated for 6 and 24 hours respectively. The 6 hour specimen has a dual microstructure while the 24 hour specimen has a ditched microstructure. The results of the oxalic acid test indicate that the samples have been sensitized and can be used to compare the localized corrosion behavior of sensitized and non-sensitized material.

EPR has been used to quantitatively determine the degree of sensitization of welded and flame washed 304 pipe sections in the process water system at SRS. EPR values for flame washed regions on the outer diameter of the pipe range from about $5-20 \mathrm{C} / \mathrm{cm}^{2}, 6$ while for pipe butt welds the values are approximately $15 \mathrm{C} / \mathrm{cm}^{2} .^{7}$ The EPR values determined for the solution-annealed, 6 hour and 24 hour specimens used in the electrochemical tests were $0.0027,6.2$ and 13.7 $\mathrm{C} / \mathrm{cm}^{2}$ respectively. Thus, the sensitization levels of the materials which were tested approximate those in the heat affected zones of welded 304 pipe. Figures 4. 5, and 6 show post-EPR microstructures for these specimens. The micrographs of the sensitized microstructures indicate that the grain boundaries were preferentially etched.

\section{Cyclic Polarization Tests}

The purpose of these tests was 10 investigate whether sensitization of 304 adversely affected its localized corrosion behavior in a gadolinium nitrate environment. Cyclic polarization is an electrochemical technique which provides a quick assessment of a material's susceptibility to pitting. Figure 7 illustrates how a cyclic polarization curve may be utilized to assess pitting susceptubility. Initially, the potential is scanned from the corrosion or open circuit potential (Ecorr) towards more positive potentials. Since stainless steels possess a protective oxide film at the surface, the current density remains quite low over a wide potential range. At a high positive potential, a significant increase in the current density occurs. This potential (Eb) may indicate the initiation of pitting, or it may be another anodic reaction occurring at the oxide surface. At a current density of $5 \mathrm{~mA} / \mathrm{cm}^{2}$ the scan is reversed, and the potential is returned to $E_{\text {corr. }}$. Pitting susceptibility is indicated if the retum scan current density at potentials less than $E_{b}$ exceeds that of the forward scan by more than an order of of magnitude ${ }^{8}$ (negative hysteresis). Conversely, if the current density of the reverse scan is less than that of the forward scan (positive hysteresis) the specimen is not susceptible to pitting. 
A matrix giving conditions for each scan is shown below:

\begin{tabular}{|c|c|c|}
\hline Specimen & Heat Treatment Time $(\mathrm{hr})$ & Solution $\mathrm{pH}$ \\
\hline A & solution annealed & 3.39 \\
B & solution annealed & 3.39 \\
C & 6 & 2.07 \\
D & 6 & 3.39 \\
E & 24 & 3.39 \\
\hline
\end{tabular}

Figure 8 shows the polarization curve for the 24 hour specimen conducted in the as-mixed gadolinium nitrate solution. During the forward scan the current density remains quite low over a wide potential range of approximately $1.2 \mathrm{~V}$. This result demonstrates that the oxide film protects the material very well in the gadolinium nitrate environment. The current density during the initial portion of the return scan is slightly greater than that of the forward scan. This result indicates a small amount of crevice corrosion which frequently occurs during these tests under a gasket at the edge of the specimen. However, from $+1000 \mathrm{mV}, E_{b}$, back to $E_{c o r r}$ the current density of the reverse scan is less than that of the forward scan. Thus, 304 is not susceptible to pitting in the gadolinium nitrate environment. As confirmation of this result, microscopical observation revealed no pits on the specimen face.

Similar results were obtained for polarization tests performed on the solution annealed and 6-hour specimens in the as-mixed gadolinium nitrate solution, as well as for the 6 -hour specimen in an acidified solution. Therefore, localized corrosion of 304 is not anticipated in the gadolinium nitrate environment regardless of the degree of sensitization of the material.

\section{Immersion Tests}

Although electrochemical testing serves as a good predictor of the corrosion behavior of a material in a particular environment, coupon immersion tests are frequently performed to confirm these predictions. Inmersion testing involves exposing specimens to environments that simulate anticipated field conditions for a period of several days or weeks. The specimens are then examined to determine the extent of corrosion.

Immersion testing of $304 \mathrm{~L}$ rods in simulated SSS ink was performed previously in a study of the corrosion of liquid level conductivity probes used in the main ink storage tanks, probe pots, and reservoir tanks of the SSS. 304L rods in an as-received condition were exposed to solutions of gadolinium nitrate $(0.18$ $\mathrm{g} / \mathrm{ml} \mathrm{Gd)} \mathrm{for} \mathrm{a} \mathrm{period} \mathrm{of} \mathrm{three} \mathrm{months.} \mathrm{Variables} \mathrm{for} \mathrm{this} \mathrm{program} \mathrm{included}$ acidification of the solution to $\mathrm{pH} 2$, application of an alternating potential to the probe rod, and addition of Rhodamine $B$, a chloride-containing dye, to the 
solution. These factors, particularly the application of an alternating potential, served to increase the aggressiveness of the test environment.

Pitting was not observed on $304 \mathrm{~L}$ rods exposed to gadolinium nitrate solution containing Rhodamine $\mathrm{B}$ with $\mathrm{pH}$ values of 2 or 5 after a three-month period with no applied voltage to the rods. Nor was pitting observed under an applied voltage when the solution $\mathrm{pH}$ was raised to a value of 5 and the Rhodamine $\mathrm{B}$ was not added to the solution. These results suggest that the gadolinium nitrate solution alone, even in an acidified condition, is not sufficient to cause localized corrosion of $304 \mathrm{~L}$ in the as-reccived condition. Because the cyclic potentiodynamic polarization scans indicated no significant differences in corrosion behavior of sensitized and non-sensitized 304 in various gadolinium nitrate environments, the immersion data can be extended to suggest that 304 would not have pitted under similar test conditions.

\section{CONCLUSIONS}

The data obtained during cyclic potentiodynamic polarization scans reveal that no significant differences in corrosion behavior exist between sensitized and non-sensitized 304 in as-mixed and acidified gadolinium nitrate solutions at room temperature. These results are supported by immersion data which indicates that $304 \mathrm{~L}$ will not pit as a result of immersion in acidinied gadoliniun nitrate solutions for a period of three months. The combined data provide strong evidence that allowing the nonconforming SSS components to remain in place temporarily does not threaten the structural integrity of the system. The data corroborate the technical justification provided by the RCMC allowing for the components to remain in place until the next scheduled long reactor shut-down. 


\section{REFERENCES}

1. J. E. Marra to J. D. Spencer (Reactor Corrosion Mitigation Committee), "Meeting Minutes - May 16, 1991 (U)," SRL-MTS-913000, Westinghouse Savannah River Company, Savannah River Laboratory, Aiken, South Carolina 29808 (May 17, 1991)

2. M. H. Anderson, Laboratory Notebook, WSRC-NB-91-110, Westinghouse Savannah River Company, Savannah River Laboratory, Aiken, South Carolina 29808 (1991)

3. M. H. Anderson, "Supplementary Safety System Liquid Level Probe Corrosion Study (U)," WSRC-NB-90-505, Westinghouse Savannah River Company, Savannah River Laboratory, Aiken, South Carolina 29808 (October, 1990)

4. W. L. Clarke, "The EPR Method for the Detection of Sensitization in Stainless Steels," Prepared for U. S. Nuclear Regulatory Commission and General Electric Company, GEAP 24888, NUREG/CR-1095, (April, 1981)

5. W. L. Clarke and D. C. Carlson, "Nondestructive Measurement of Sensitization of Stainless Steel: Relation to High Temperature Stress Corrosion Behavior," Materials Performance, Vol. 19, No. 3, March, 1980.

6. K. J. Stoner, WSRC-RP-89-229, "An Evaluation of Sensitization in Type 304 Stainless Steel Pipe Sections Removed from Service (U)," Westinghouse Savannah River Company, Savannah River Laboratory, Aiken, South Carolina 29808 (July 31,1989 )

7. G. R. Caskey, R. S. Ondrejcin, R. L. Sindelar and E. W. Baumann, WSRC-TR-9112. "Effect of Neutron Irradiation on Stress Corrosion Cracking of Type 304 Stainless Steel in Simulated Savannah River Reactor Environments (U)," Westinghouse Savannah River Company, Savannah River Laboratory, Aiken, South Carolina 29808 (January., 1991)

8 P. E. Zapp, DPST-88-399, "Electrochemical Study of Corrosion Inhibition During Sludge Washing," Westinghouse Savannah River Company, Savannah River Laboratory, Aiken, South Carolina 29808 (March 14, 1988) 


\section{ATTACHMENT 1}

\section{CERTIEIED MILL TEST REPORT OF 304 MATERLAL}

\section{USED FOR TESTS}

Element
Carbon
Manganese
Phosphorus
Sulfur
Silicon
Chromium
Nickel
Molybdenum
Copper
Nitrogen
Cobalt
Iron

wit \%

0.06

1.84

0.037

0.002

0.43

18.28

8.07

0.42

0.48

0.06

0.15

bal. 


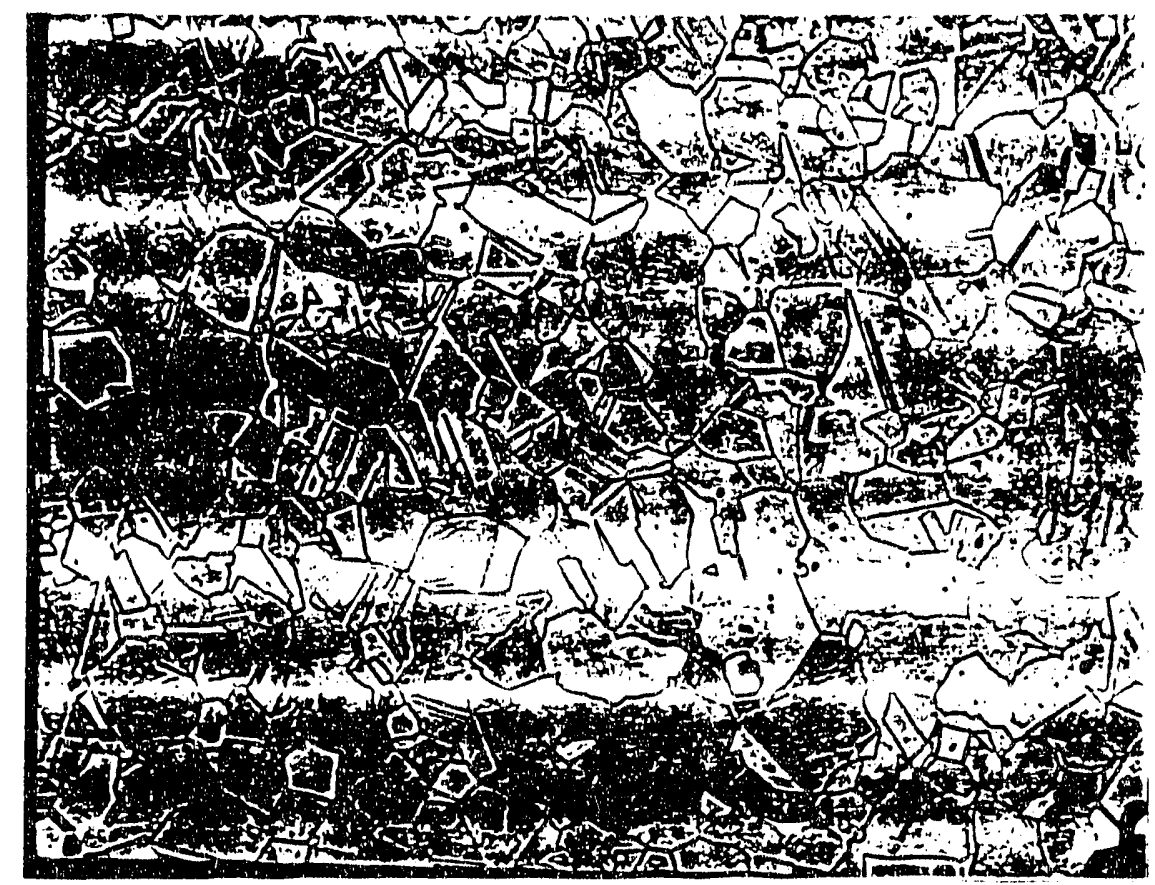

Figure 1. Oxalic Acid Etch Of Solution Annealed 304.

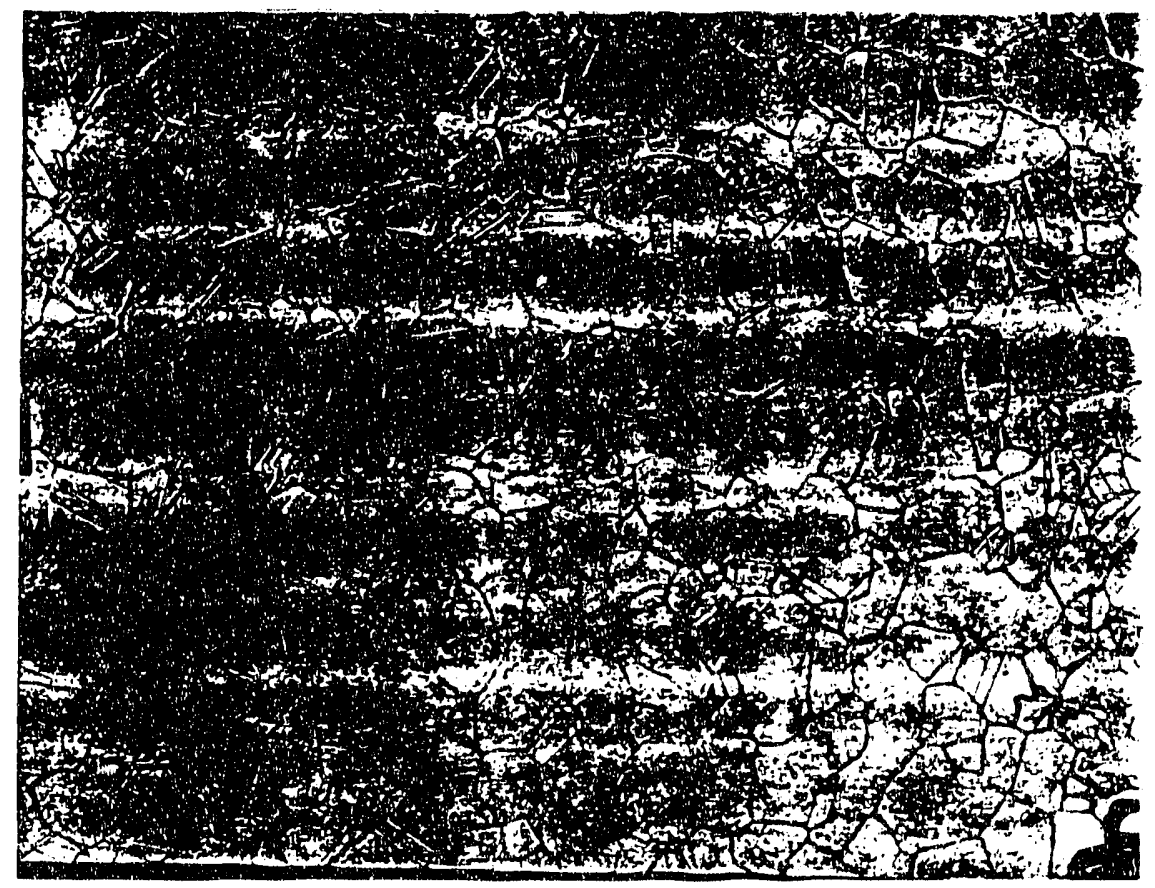

Figure 2. Oxalic acid etch of 304 that has beer heat treated for 6 hours at $650^{\circ} \mathrm{C}$. 


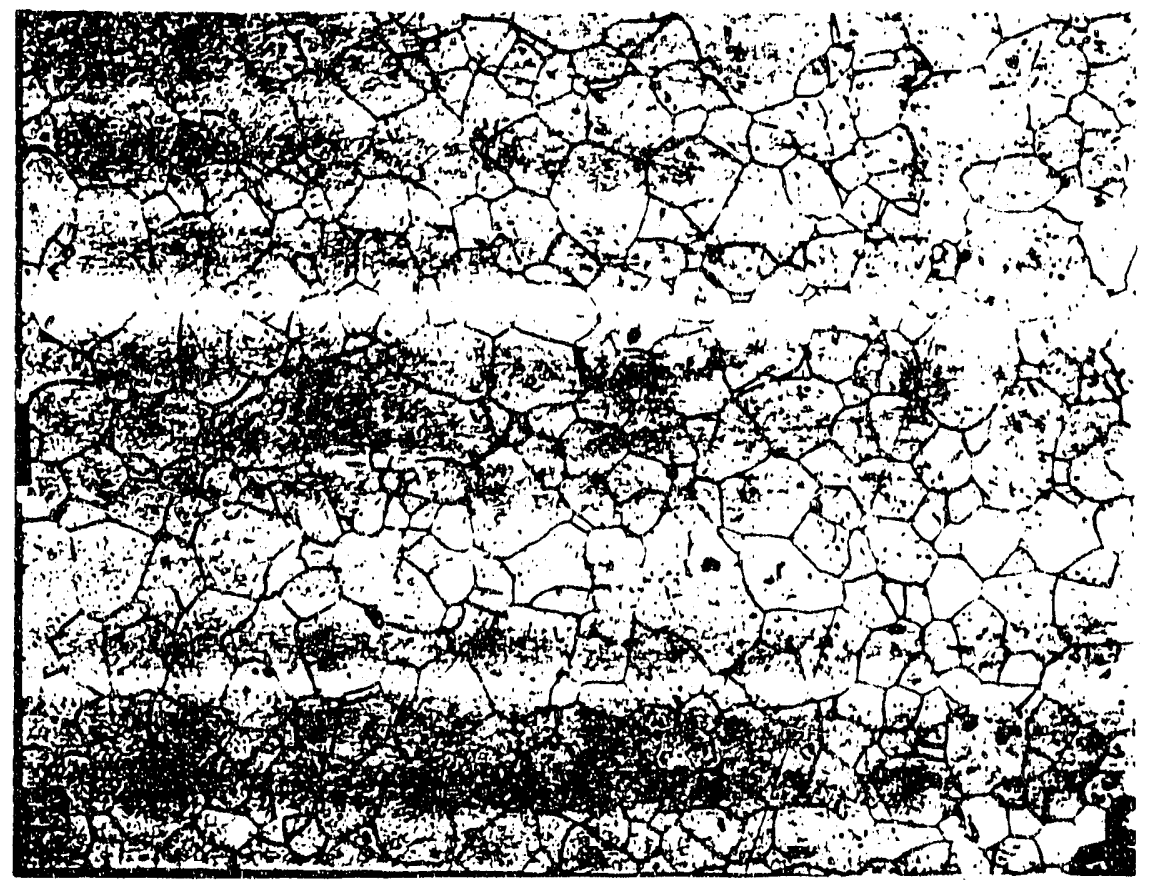

Figure 3. Oxalic Acid Etch of 304 That Has Been Heat Treated For 24 Hours At $650^{\circ}$ C.

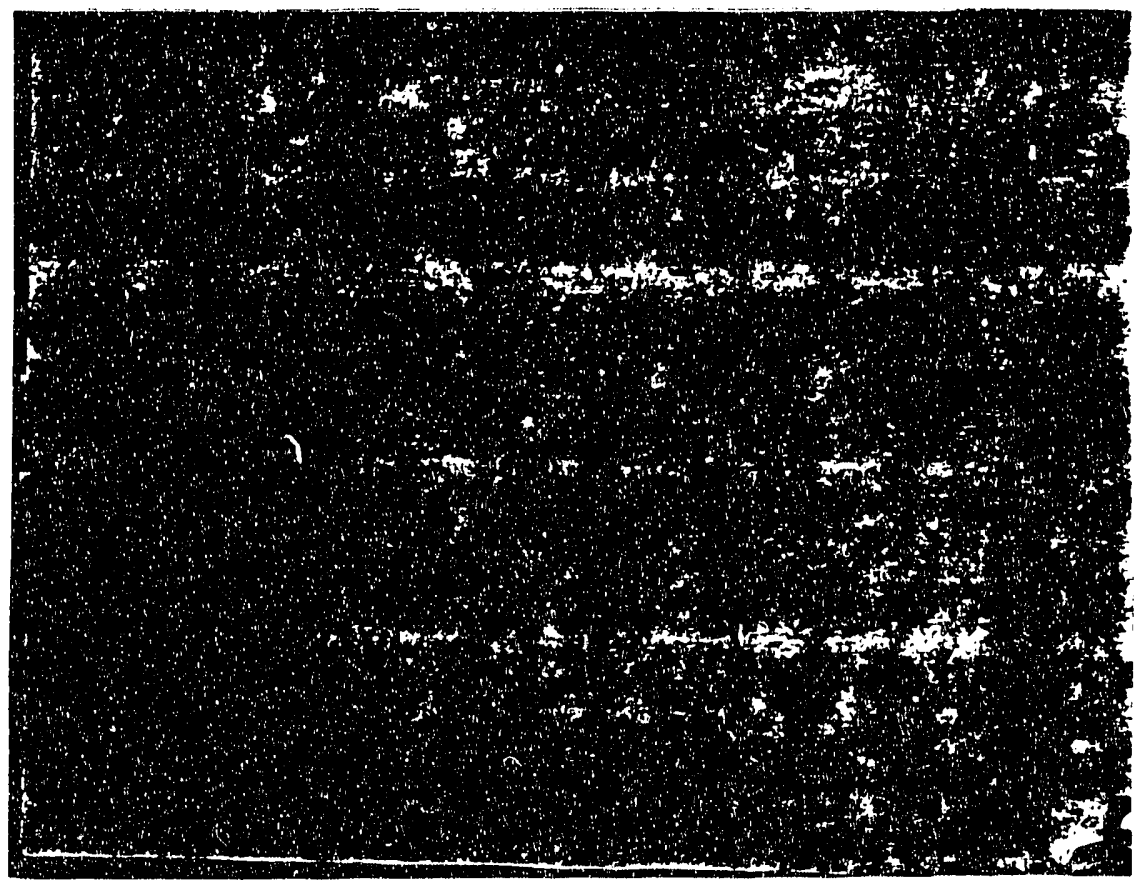

Figure 4. Post-EPR microstructure of the solution annealed 304. 


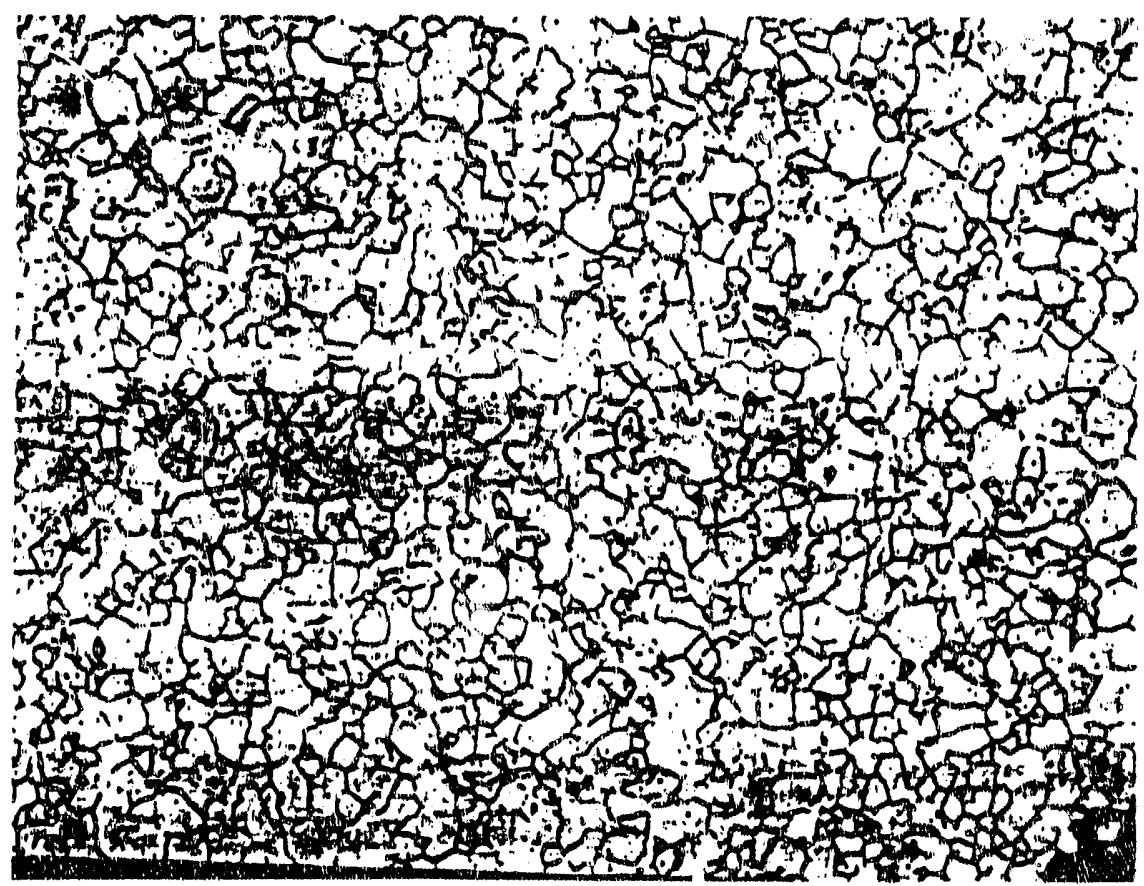

Figure 5. Post-EPR microstructure of the 304 that was heat treated for 6 hours at $650^{\circ} \mathrm{C}$.

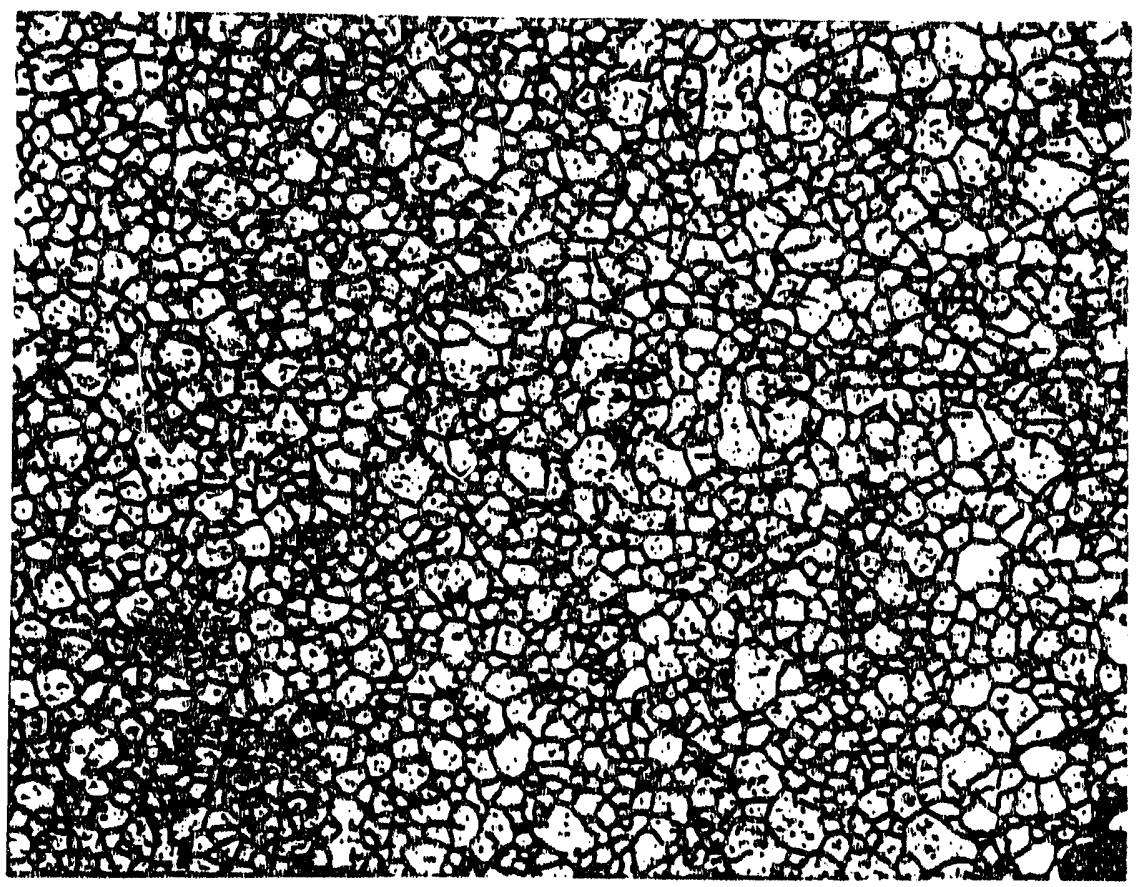

Figure 6. Post-EPR microstructure of the 304 that was heat treated for 24 hours at $650^{\circ} \mathrm{C}$. 


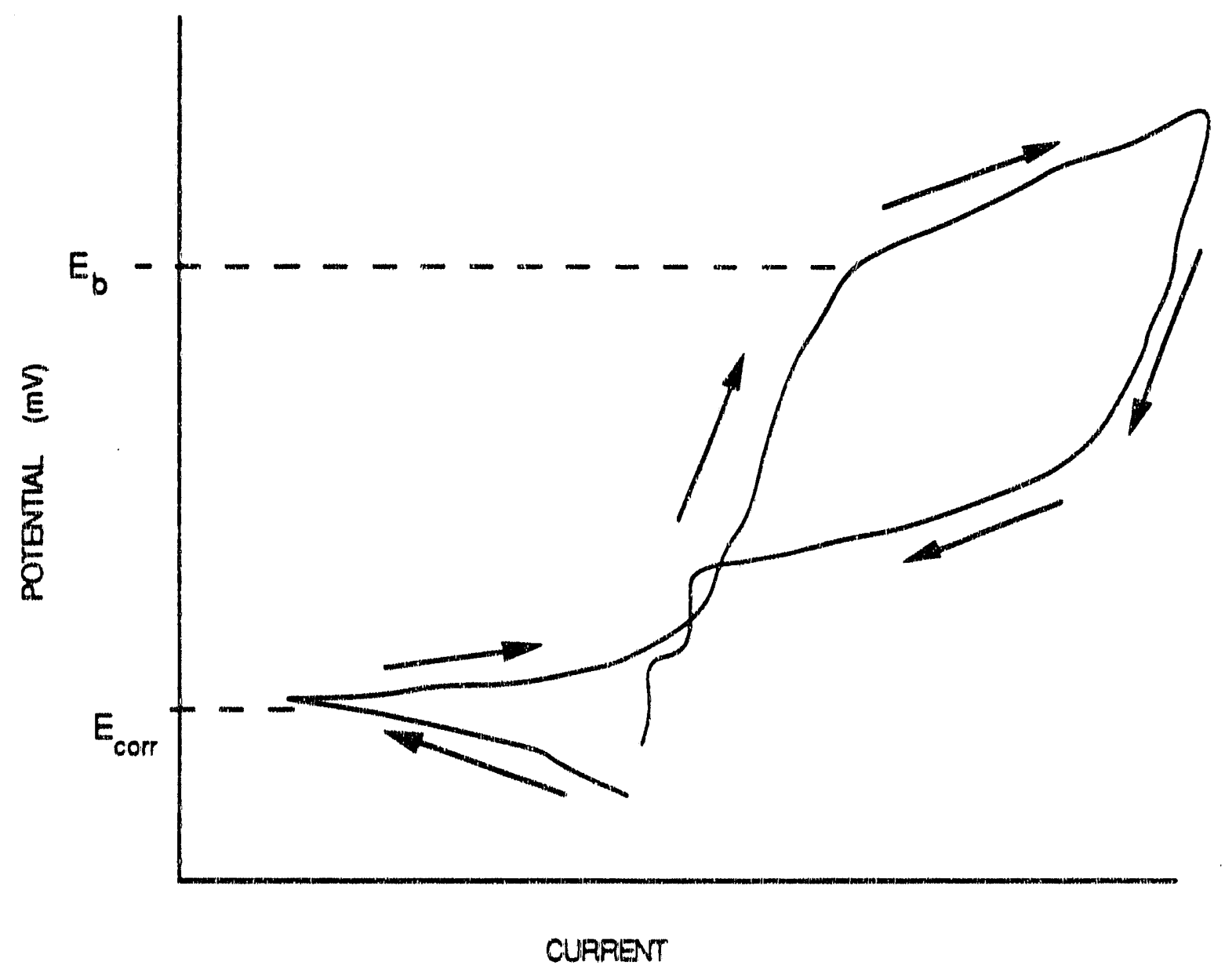

Figure 7. Example of cyclic polarization curve which illustrates pitting susceptiblittw. 
M. H. Anderson and B. J. Wiersma

WSRC.TR-91-389

UNCLASSIFIED

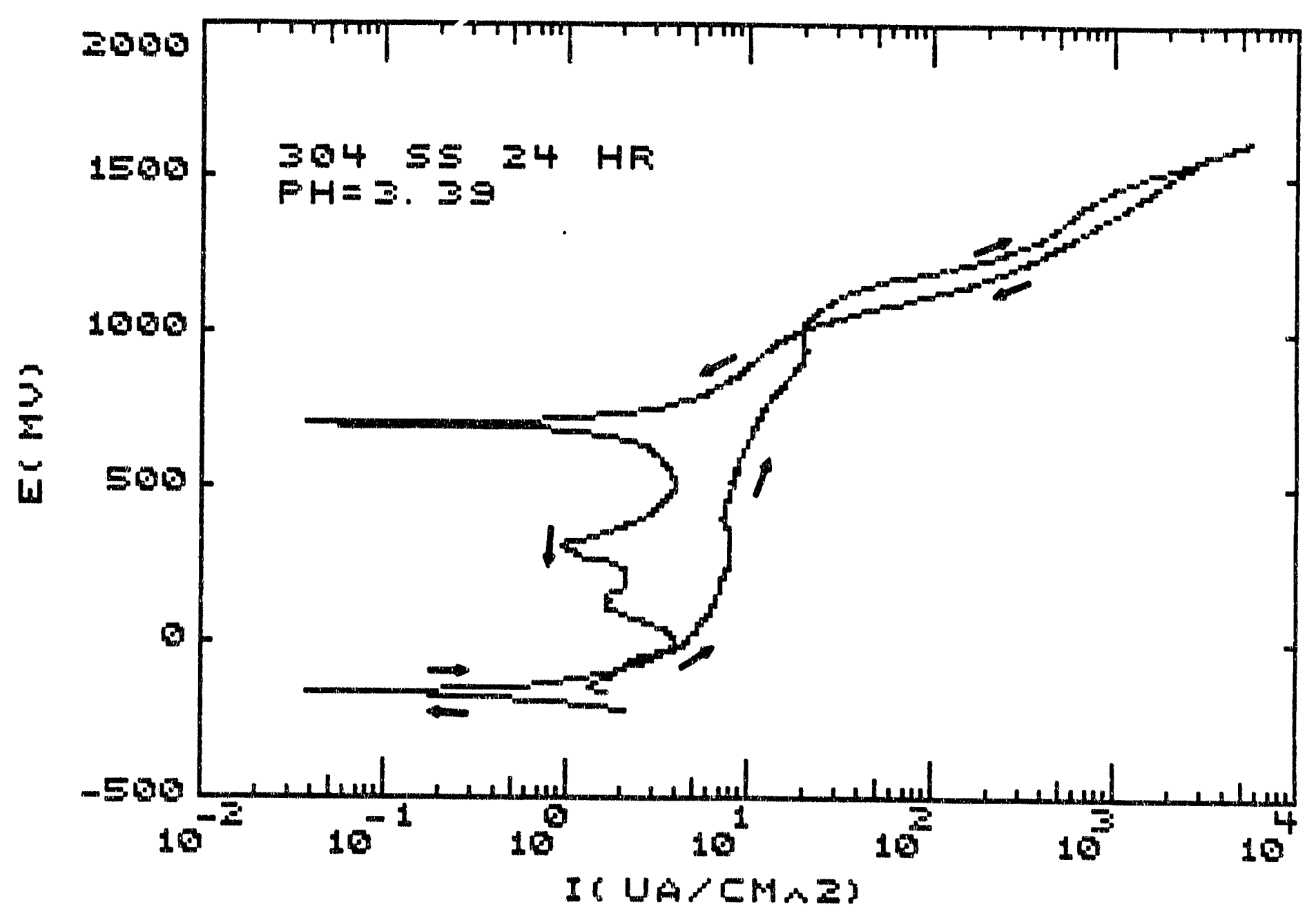

Figure 8. Cyclic polarization curve for 24 hour 304 specimen in a gadolinium nitrate solution with a pH of 3.39. 


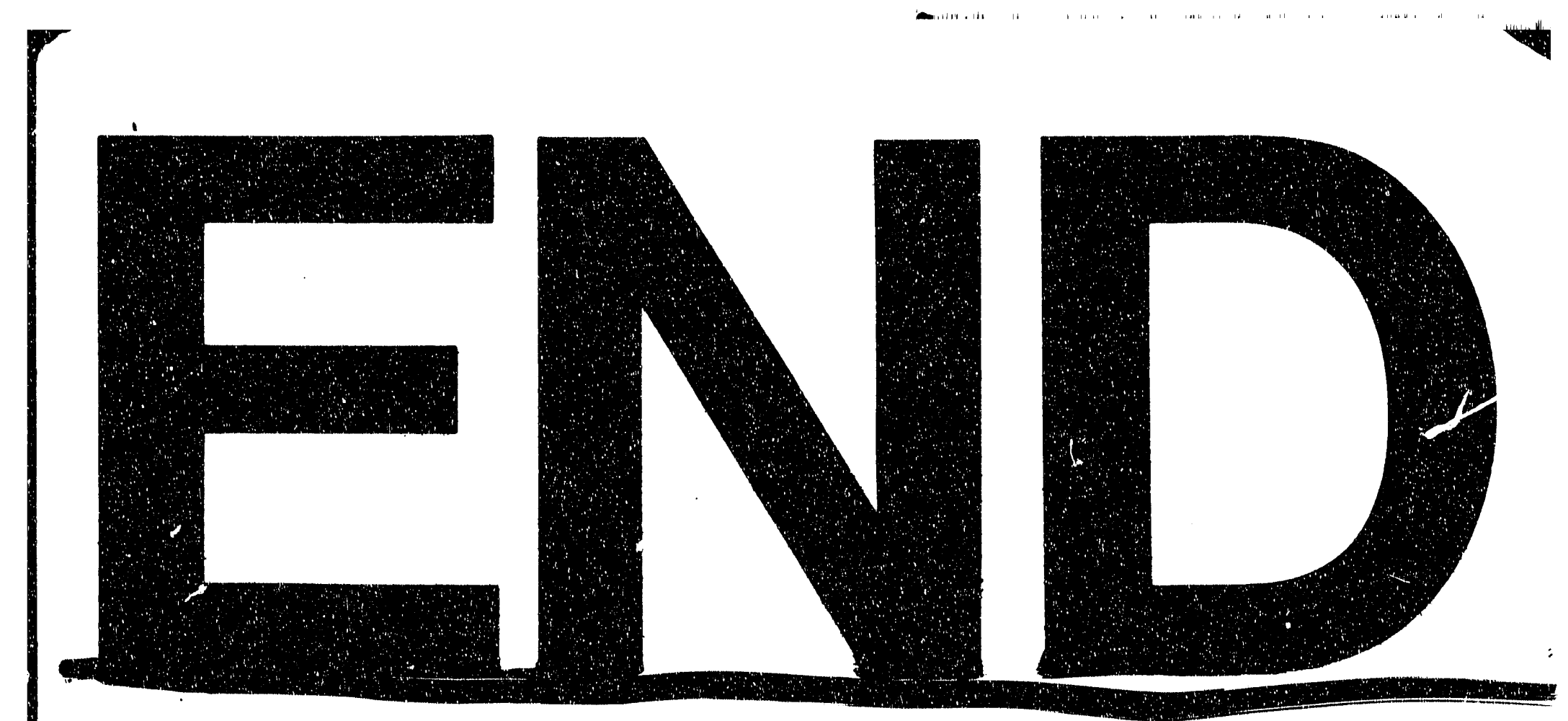




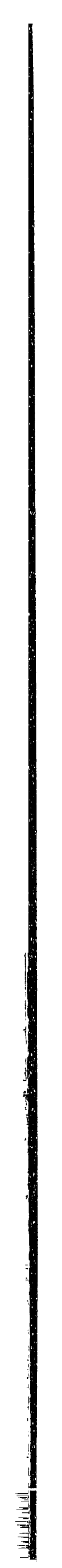

